\title{
Günlük Yaşamda Sıklıkla Tüketilen Çeşitli Besinlerin Etiket Bilgilerinin Değerlendirilmesi
}

\section{Evaluation of Label Information of Various Foods Consumed Frequently in Daily Life}

\section{Sinem Erem ${ }^{1}$, Esen Yeşil ${ }^{2}$, Aydan Ercan ${ }^{3}$, Muhittin Tayfur ${ }^{4}$}

Geliş tarihi/Received: 01.11.2017 • Kabul tarihi/Accepted: 03.04.2018

\section{ÖZET}

Amaç: $\mathrm{Bu}$ çalışmanın amacı piyasada satılmakta olan ve yüksek miktarlarda tüketilen besinlerin etiket bilgilerinin değerlendirilmesidir.

Gereç ve Yöntem: Bu çalışma İstanbul ili sınırları içerisinde bir büyük semtte faaliyet gösteren iki büyük, üç ekonomik küçük market zincirinde yürütülmüştür. Bu marketlerde toplamda 700 besin etiketi incelenmiştir. Satışa sunulan besinler, temel besinler, atıştırmalıklar, tek başına tüketilmeyen besinler, bebek ve devam mamaları, diğer besinler olmak üzere beş grupta incelenmiştir. Besinlerin etiket bilgilerinin toplanmasında besin etiket bilgileri kayıt formu kullanılmıştır.

Bulgular: Besin ambalajlarında etiket bulunma durumlarına bakıldığında temel besinler (\%84.1), atıştırmalıklar (\%84.1) ve bebek mamalarının (\%100.0) diğer besinler ve tek başına tüketilemeyen besinlerin çoğunluğunda etiketin olduğu saptanmıştır $(\mathrm{p}<0.001)$. Besin etiketlerinin \%1.3'ünde gramaj bilgileri verilmez iken, temel besinlerin \%82.4'ünde, atıştırmalıkların \%99.3'ünde, bebek mamalarının tamamında, diğer besinlerin ise \%90.4'ünde net ağırlık verilmiştir. Besin grupları arasında ağırlık beyanı çeşidine göre istatistiksel olarak anlamlı ilişki saptanmıştır $(\mathrm{p}<0.001)$. Besin gruplarına göre etiketlerinde üretici ve paketleyici firma adı bulunma yüzdeleri temel besinlerde, atıştırmalıklarda, tek başına tüketilmeyen besinlerde, bebek mamalarında ve diğer besinlerde sırasıyla \%97.1, \%95.7, \%96.7, \%100.0, \%100.0’dür ( $p=0.33$ ). Gruplar arasında son tüketim tarihi açısından istatistiksel olarak anlamlı fark bulunmuştur $(\mathrm{p}<0.001)$. Temel besinlerin \%36.4'ünün, atıştırmalıkların \%23.4’ünün, tek başına tüketilmeyen besinlerin \%22.0’sinin, bebek mamalarının \%42.1'inin, diğer besinlerin ise \%16.9'unun enerji değerlerinin etikette verilen verilerden hesaplanan enerjiyi tam olarak sağladığı bulunmuştur. Yanlış değer olarak hesaplanan besin grubunun atıştırmalıklar olduğu saptanmıştır.

Sonuç: Bu çalışmanın sonucunda, tüketicilerin kullanımına sunulan ve satış mağazalarında yer verilen besinlerin beslenme bilgileri açısından etiket bilgilerini tam olarak karşılayamadığı ancak ticari bilgiler açısından yeterliliklerin yüksek düzeyde karşılandı̆̆ı belirlenmiştir.

Anahtar kelimeler: Besin etiketi, besin değeri etiketi, tüketici algısı

\section{ABSTRACT}

Aim: The aim of this study was to evaluate the label information of various foods consumed frequently in daily life.

1. Ankara Üniversitesi Beslenme ve Diyetetik Bölümü, Ankara, Türkiye (D) https://orcid.org/0000-0002-3849-0805

2. İletişim/Correspondence: Başkent Üniversitesi Beslenme ve Diyetetik Bölümü, Ankara, Türkiye • E-posta: esezer@baskent.edu.tr

(D) https://orcid.org/0000-0003-0234-204X
3. Başkent Üniversitesi Beslenme ve Diyetetik Bölümü, Ankara, Türkiye (D) https://orcid.org/0000-0003-1132-3908

4. Başkent Üniversitesi Beslenme ve Diyetetik Bölümü, Ankara, Türkiye (D) https://orcid.org/0000-0003-3645-5579 
Material and Methods: This study was conducted in two major and three small market economies chains operating in one large region in İstanbul. A total of 700 food labels have been examined. The food served in the sale was examined in five groups; fundamental foods, snacks, foods that can not be consumed alone, infant and follow-up formulas, other foods. Food label information record form was used to collect food label information.

Results: According to given the presence or absence of food labels on the packages, it was determined that number of labels of fundamental foods (84.1\%), snacks (84.1\%) and infant and follow-up formulas (100.0\%) were higher than the other foods and foods that can not be consumed alone items $(\mathrm{p}<0.001)$. No weight information was given at $1.3 \%$ of the packages. Net weight was given in $82.4 \%$ of the fundamental foods, $99.3 \%$ of the snacks and $90.4 \%$ of the other foods. All baby foods are given as net weight $(\mathrm{p}<0.001)$. Percentage of manufacturer and packer company name in their packaging in fundamental foods, snacks, foods that can not be consumed alone, baby food and other foods were $97.1 \%, 95.7 \%, 96.7 \%, 100.0 \%$ and $100.0 \%$, respectively ( $p>0.05$ ). There was a statistically significant difference between the groups in terms of the expiry date ( $p<0.001$ ). In this study $36.4 \%$ of the fundamental foods, $23.4 \%$ of the snacks, $22.0 \%$ of the foods that can not be consumed alone foods, $42.1 \%$ of the baby foods and $16.9 \%$ of the other foods have been found that the energy values fully provide the energy calculated from the given nutrition facts data. The energy values of snack foods did not comply the given values.

Conclusion: As a result of this study, it was determined that the food products offered to the consumers and included in the sales stores did not fully meet the labeling information in terms of nutritional information, but the competence in terms of commercial information was high.

Keywords: Food label, nutrition label, product reference

\section{GİRIŞ}

Vücudun gereksinimi olan besin ögelerini yeterli ve dengeli almak amacıyla bilinçli yapılması gereken bir eylem olarak tanımlanan ve bireylerin yaşamlarını doğrudan etkileyen beslenme, psikolojik, sosyal, ekonomik özellikler olmak üzere pek çok etmenle ilişkili fizyolojik bir süreçtir (1).

Beslenme ile yakından ilişkili olarak sağlığın korunması, geliştirilmesi, yaşam kalitesinin yükseltilmesi, hastalık risklerinin azaltılması için yürütülen tüm çalışmalarda doğru besin seçimi yapabilmek için besin etiket bilgileri büyük önem taşımaktadır (1,2-4). Dünya Sağlık Örgütü (DSÖ)’nün Beslenme, Fiziksel Aktivite ve Sağlık Global stratejileri içerisinde sağlıklı besin seçimi ve etiket ile ilgili çalışmalarda yer alması, çalışmalara besin sanayinin etkin bir şekilde katılımı da ayrıca büyük önem taşımaktadır (5).

Tüketicilere ürün içeriği ile ilgili bilgi vermesi nedeniyle o besinin kimliği olarak kabul edilen besin etiketlerinin taşıması gereken nitelikler, 11/6/2010 tarihli ve 5996 sayll "Veteriner Hizmetleri, Bitki
Sağlığı, Gıda ve Yem Kanunu”nun ilgili maddelerine dayanılarak hazırlanan "Türk Gıda Kodeksi Gıda Etiketleme ve Tüketicileri Bilgilendirme Yönetmeliği 26.01.2017 tarihli Resmi Gazetenin 29960 nolu mükerrer sayısı”nda yayımlanmıştır. $\mathrm{Bu}$ yönetmeliğin amacı, algı farklılıkları ve bilgi gereksinimleri dahil besin konusunda bilgilendirme açısından tüketicilerin üst düzeyde korunmasına ilişkin kuralları belirlemektir (6). Bilinçli satın alma ve sağlıklı beslenme için tüketicinin yapabileceği en önemli davranış biçiminin besin etiketlerinin okunması olduğu belirtilmektedir $(2,7)$.

Besin ambalajında etiket, ilgili mevzuatta belirtildiği üzere fiziksel, kimyasal, kullanım, saklama özellikleri, besin ögesi içeriği ve ticari bilgileri bulundurabilmektedir (8). Yapılan bir çalışmada katılımcıların \%20'sinden fazlası besin değeri bilgilerini "nadiren" okumakta ya da "hiçbir zaman” okumamaktadır (2). Türkiye'de yapılan bir başka kesitsel çalışmada katılımcıların \%76.5’inin besin etiketini, \%72.4'ünün ise beslenme bilgilerini okudukları saptanmıştır (9). 
Ambalajlı besinlerin büyük çoğunluğu için, etiketleri üzerinde beslenme bildirimi yapılması zorunludur. Beslenme yönünden etiketleme bilgileri, besinin enerji değerini ve besindeki her bir anahtar besin ögesinin miktarını içermektedir (9). Ayrıca besinin içerdiği vitamin ve minerallerin bu tabloda yer alabilmesi için, tebliğde belirlenen beslenme referans değerinin (BRD) en az \%15'ini karşılaması gerekmektedir. Ayrıca, vitaminler ve mineraller ile ilgili bilgiler, beslenme referans değerlerinin yüzdesi olarak da belirtilmelidir (10-12). Bu bilgiler yalnızca tüketicilerin değil başta obezite dahil olmak üzere tüm sistemik/metabolik hastalıklarda tıbbi beslenme tedavisini hazırlayan ve yürüten, bireylere sağlıklı beslenme davranışı kazandırmayı amaçlayan diyetisyenlerin de doğru besin seçimine yardımcı olmaktadır $(10,13)$.

$\mathrm{Bu}$ çalışma, satışa sunulmuş bazı besinlerin etiket bilgilerinin değerlendirilmesi amacıyla planlanmış ve yürütülmüştür.

\section{GEREÇ VE YÖNTEM}

\section{Araştırma Verilerinin Toplanması Ve Örneklem Seçimi}

$\mathrm{Bu}$ çalışmada, Türkiye’nin tüm illerinde mağazası bulunanan iki büyük ve üç ekonomik küçük zincir marketin, İstanbul ili Beşiktaş ilçesindeki şubelerinde satışa sunulmuş besinlerin etiketleri incelenmiştir. Çalışma için etiketi toplanan 700 besin, beslenme ve sağlık beyanı açısından 5 ayrı grupta incelenmiştir. Bu gruplar:

1. Temel besinler (TB): Ambalajlı ekmekler, bakliyatlar ve tahıllar, zeytinler, sütler ve ürünleri, yumurta, soğuk veya dondurulmuş et ürünleri gibi temel besinlerdir.

2. Atıştırmalıklar (A): Kekler, bisküviler, gofretler, patates/mısır çerezleri, kahvaltılık gevrekler, dondurmalar, tatlılar, çikolatalar gibi enerji değeri yüksek ve beslenme değeri düşük besinlerdir.

3. Tek başına tüketilmeyen besinler (TBTB): Unlar, et suları, yufka, sıvı ve katı yağlar, tuz, soslar, sirkeler, şekerler gibi bir yiyeceğin bileşimine giren besinlerdir.

4. Bebek mamaları (BM): Bebek ve çocuklar için üretilen toz ve kaşık mamalarıdır.

5. Diğer besinler (DB): Enerji içecekleri, gazlı/gazsız içecekler, kavanoz turşuları gibi besinlerdir.

Besinlerin etiket bilgilerinin toplanmasında, "Türk Gıda Kodeksi Gıda Etiketleme ve Tüketicileri Bilgilendirme Yönetmeliği” dördüncü bölümünde yer alan "Gıda Hakkında Zorunlu Bilgilendirmenin İçeriği ve Bildirimi Zorunlu Bilgiler (Madde 9)” esas alınarak hazırlanan kayıt formu kullanılmıştır (6).

Besinin enerji değeri etiket üzerinde yer alan bilgilerle makro besin ögeleri miktarlarına göre hesaplanmıştır (4 kkal/g CHO + 4 kkal/g protein + $9 \mathrm{kkal} / \mathrm{g}$ yağ).

\section{İstatistiksel Değerlendirme}

Çalışma verilerinin değerlendirilmesinde iki veya daha fazla bağımsız grup yüzdesi arasındaki farkın karşılaştırılmasında ki-kare testi kullanılmış, anlamlllık incelenirken veri gözlerinde 5’ten küçük beklenen frekans yüzdesi eğer \%20.0'den küçük ise Pearson ki-kare testi, \%20-25 arasinda ise Likehood ki-kare istatistiği, \%25.0’ten büyük ise Fisher Exact test istatistiği kullanılmıştır. Bütün istatistiksel analizlerde önemlilik düzeyi olarak $\mathrm{p}<0.05$ ve $\mathrm{p}<0.001$ kabul edilmiştir. Verilerin değerlendirilmesinde SPSS 21.0 programından yararlanılmıştır.

\section{BULGULAR}

Çalışma süresince incelenen paketli besinlerden BM'nın \%100.0'ünde, TB'in ve A'ın \%84.1'inde, DB'in \%69.9'unda ve TBTB'in \%74.0'ünde besin etiketi bulunduğu saptanmıştır (Tablo 1). BM'nın \%100’ünde zorunlu bulunması gereken besin içeriği bilgileri eksiksiz yer alırken TB'in \%15.1'inde bilgilerin eksik olduğu ve TBTB'in \%44.9'unda herhangi bir etiket bulunmadığı saptanmış, gruplar arasındaki fark istatistiksel olarak önemli bulunmuştur (Tablo 1) $(\mathrm{p}<0.001)$. 
Tablo 1. Besin etiket ve ambalajlarının fiziksel görünüş özellikleri

\begin{tabular}{|c|c|c|c|c|c|c|c|c|c|c|c|c|c|}
\hline \multirow{3}{*}{$\begin{array}{l}\text { Besin etiketlerinde bulunan } \\
\text { nitelikler }\end{array}$} & \multicolumn{12}{|c|}{ Besin grupları } & \multirow{3}{*}{$\mathbf{p}$} \\
\hline & \multicolumn{2}{|c|}{$\begin{array}{c}\text { TB }^{1} \\
(n=239)\end{array}$} & \multicolumn{2}{|c|}{$\begin{array}{c}A^{2} \\
(n=145)\end{array}$} & \multicolumn{2}{|c|}{$\begin{array}{c}\text { TBTB }^{3} \\
(n=214)\end{array}$} & \multicolumn{2}{|c|}{$\begin{array}{c}\text { BM }^{4} \\
(n=19)\end{array}$} & \multicolumn{2}{|c|}{$\begin{array}{c}\mathrm{DB}^{5} \\
(\mathrm{n}=83)\end{array}$} & \multicolumn{2}{|c|}{$\begin{array}{l}\text { Toplam } \\
(n=700)\end{array}$} & \\
\hline & $\mathbf{n}$ & $\%$ & $\mathbf{n}$ & $\%$ & $\mathbf{n}$ & $\%$ & $\mathbf{n}$ & $\%$ & $\mathbf{n}$ & $\%$ & $\mathbf{n}$ & $\%$ & \\
\hline Ambalajında etiket bulunma durumu & 201 & 84.1 & 122 & 84.1 & 118 & 55.1 & 19 & 100.0 & 58 & 69.9 & 518 & 74.0 & $<0.001^{\mathrm{a} 1}$ \\
\hline \multicolumn{14}{|l|}{ Etiket gramaj bilgisi } \\
\hline Brüt & 3 & 1.3 & - & - & 10 & 4.7 & - & - & - & - & 13 & 1.9 & \\
\hline Net & 197 & 82.4 & 144 & 99.3 & 199 & 93.0 & 19 & 100.0 & 75 & 90.4 & 634 & 90.6 & $0.00^{\mathrm{b} 123}$ \\
\hline Brüt + net & 33 & 13.8 & 1 & 0.7 & 2 & 0.9 & - & - & 8 & 9.6 & 44 & 6.3 & \\
\hline \multicolumn{14}{|l|}{ Etiket bilgileri } \\
\hline Tam & 165 & 69.0 & 104 & 71.7 & 88 & 41.1 & 19 & 100.0 & 50 & 60.2 & 426 & 60.9 & \multirow{2}{*}{$<0.001^{\mathrm{a} 35}$} \\
\hline Eksik & 36 & 15.1 & 18 & 12.4 & 30 & 14.0 & - & - & 8 & 9.6 & 92 & 13.1 & \\
\hline $\begin{array}{l}\text { Etiketteki tüm yazılar fonla kontrast } \\
\text { şekilde }\end{array}$ & 233 & 97.5 & 130 & 89.7 & 202 & 94.4 & 19 & 100.0 & 78 & 94.0 & 662 & 94.6 & $0.01^{\mathrm{c} 1}$ \\
\hline $\begin{array}{l}\text { Etiketteki tüm yazılar silinmez } \\
\text { karakterde }\end{array}$ & 236 & 98.7 & 138 & 95.2 & 207 & 96.7 & 19 & 100.0 & 82 & 98.8 & 682 & 97.4 & $0.23^{\mathrm{b} 1}$ \\
\hline $\begin{array}{l}\text { Etiketteki tüm yazılar, okunabilir } \\
\text { renk }\end{array}$ & 230 & 96.2 & 128 & 88.3 & 208 & 97.2 & 19 & 100.0 & 75 & 90.4 & 660 & 94.3 & $<0.001^{\mathrm{c} 2}$ \\
\hline $\begin{array}{l}\text { Etiketteki tüm yazılar, okunabilir } \\
\text { boyutta }\end{array}$ & 217 & 90.8 & 116 & 80.0 & 186 & 86.9 & 19 & 100.0 & 56 & 67.5 & 594 & 84.9 & $<0.001^{\mathrm{a} 134}$ \\
\hline $\begin{array}{l}\text { Etiketteki zorunlu bilgiler başka } \\
\text { yazılar ya da resimlerle örtülü veya } \\
\text { kesik değil }\end{array}$ & 190 & 80.8 & 110 & 75.9 & 115 & 53.7 & 19 & 100.0 & 53 & 63.9 & 490 & 70.0 & $<0.001^{\mathrm{c} 3}$ \\
\hline $\begin{array}{l}\text { Etikette yanıltıcı etki ve özellikler } \\
\text { bulunmuyor }\end{array}$ & 192 & 79.5 & 110 & 75.9 & 115 & 53.7 & 19 & 100.0 & 53 & 63.9 & 487 & 69.6 & $<0.001^{\mathrm{b} 45}$ \\
\hline $\begin{array}{l}\text { Etikette tüketiciyi yanıltacak resim, } \\
\text { şekil ve benzerlerini içermiyor }\end{array}$ & 231 & 96.7 & 138 & 95.2 & 206 & 96.3 & 19 & 100.0 & 83 & 100.0 & 677 & 96.7 & $0.326^{b}$ \\
\hline $\begin{array}{l}\text { Etikette hastalık önleme, iyileştirme } \\
\text { ve tedavi etme özelliği olduğunu } \\
\text { bildiren veya ima eden ifadeler yer } \\
\text { allyor }\end{array}$ & 14 & 5.9 & 11 & 7.6 & 17 & 7.9 & - & - & 4 & 4.8 & 46 & 6.6 & $0.583^{a}$ \\
\hline
\end{tabular}

Tüm besin etiketlerinin \%90.6'sında ürünün net, \%1.9'unda yalnızca brüt ağırlık bilgisinin yer aldığı ve yönetmelikte zorunlu olmasına rağmen etiketlerin \%1.3'ünde ağırlık bilgisi bulunmadığı görülmüş, gruplar arasındaki fark istatistiksel olarak önemli bulunmuştur (Tablo 1) $(\mathrm{p}<0.001)$.

Besin etiket yönetmeliğine göre tüm besin etiketlerinde zorunlu bulunması gereken beslenmeye ve besin güvenliğine yönelik bilgiler incelendiğinde üretici, paketleyici firmanın adı (\%97.0), imalatçı, ambalajlayıcı, ithalatçı, ihracatçı veya dağıtıcı firmanın ticari unvanı (\%98.4), açık adresi (\%95.1), üretim yeri (\%97.1), tescilli markası (\%97.6), adresi ve üretildiği yer (\%98.0) yasal düzenlemelerde belirtilen ticari nitelikteki bilgilerin yüksek düzeyde bulunduğu saptanmıştır.

TB ve A'da birer, TBTB'da 2 besin etiketinde bulunmadığ 1 görülmüştür. Besin etiketlerinde muhafaza koşulları bilgilerinin TB, A, TBTB'da sirasiyla \%93.7, \%87.6, \%89.3'ünde, BM ve DB'in ise sırasıyla \%57.9, \%65.1'inde olduğu saptanmıştır $(\mathrm{p}<0.001)$ (Tablo 2).

Besin etiketlerinde verilen beslenme bilgileri Tablo 3’te gösterilmiştir. Besin etiketlerinde bildirilen enerji değerleri yine etiket üzerinde verilen makro besin 
Tablo 2. Besin etiketlerinde bulunan ticari bilgiler

\begin{tabular}{|c|c|c|c|c|c|c|c|c|c|c|c|c|c|}
\hline \multirow{3}{*}{$\begin{array}{l}\text { Besin etiketlerinde bulunan } \\
\text { nitelikler }\end{array}$} & \multicolumn{12}{|c|}{ Besin grupları } & \multirow{3}{*}{$\mathbf{p}$} \\
\hline & \multicolumn{2}{|c|}{$\begin{array}{c}\text { TB }^{1} \\
(n=239)\end{array}$} & \multicolumn{2}{|c|}{$\begin{array}{c}A^{2} \\
(n=145)\end{array}$} & \multicolumn{2}{|c|}{$\begin{array}{c}\text { TBTB }^{3} \\
(n=214)\end{array}$} & \multicolumn{2}{|c|}{$\begin{array}{c}\mathrm{BM}^{4} \\
(\mathrm{n}=19)\end{array}$} & \multicolumn{2}{|c|}{$\begin{array}{c}D^{5} \\
(n=83)\end{array}$} & \multicolumn{2}{|c|}{$\begin{array}{l}\text { Toplam } \\
(n=700)\end{array}$} & \\
\hline & $\mathbf{n}$ & $\%$ & $\mathbf{n}$ & $\%$ & $\mathbf{n}$ & $\%$ & $\mathbf{n}$ & $\%$ & $\mathbf{n}$ & $\%$ & $\mathbf{n}$ & $\%$ & \\
\hline Üretici, paketleyici firmanın adı & 232 & 97.1 & 138 & 95.2 & 207 & 96.7 & 19 & 100.0 & 83 & 100.0 & 679 & 97.0 & $0.33^{\mathrm{b}}$ \\
\hline $\begin{array}{l}\text { İmalatçı,ambalajlayıcı, ithalatçı, } \\
\text { ihracatçı veya dağıtıcı firmanın ticari } \\
\text { unvanı }\end{array}$ & 236 & 98.7 & 142 & 97.9 & 210 & 98.1 & 19 & 100.0 & 82 & 98.8 & 689 & 98.4 & $0.94^{\mathrm{b}}$ \\
\hline $\begin{array}{l}\text { İmalatçı, ambalajlayıcı, ithalatçı, } \\
\text { ihracatçı veya dağıtıcı firmanın açık } \\
\text { adresi }\end{array}$ & 227 & 95.0 & 141 & 97.2 & 201 & 93.9 & 19 & 100.0 & 78 & 94.0 & 666 & 95.1 & $0.36^{c}$ \\
\hline $\begin{array}{l}\text { İmalatçı, ambalajlayıcı, ithalatçı, } \\
\text { ihracatçı veya dağıtıcı firmanın } \\
\text { üretim yeri }\end{array}$ & 229 & 95.8 & 145 & 100.0 & 205 & 95.8 & 19 & 100.0 & 82 & 98.8 & 680 & 97.1 & $0.05^{\mathrm{b} 2}$ \\
\hline Tescilli markası & 234 & 97.9 & 142 & 97.9 & 205 & 95.8 & 19 & 100.0 & 83 & 100.0 & 683 & 97.6 & $0.31^{\mathrm{b}}$ \\
\hline Adresi ve üretildiği yer & 231 & 96.7 & 145 & 100.0 & 211 & 98.6 & 19 & 100.0 & 80 & 96.4 & 686 & 98.0 & $0.10^{\mathrm{b}}$ \\
\hline \multicolumn{14}{|l|}{ Son tüketim tarihi } \\
\hline $\mathrm{g} / \mathrm{a} / \mathrm{y}$ & 192 & 80.3 & 117 & 80.7 & 137 & 64.0 & 19 & 100.0 & 67 & 80.7 & 532 & 76.0 & \\
\hline $\mathrm{a} / \mathrm{y}$ & 11 & 4.6 & 17 & 11.7 & 39 & 18.2 & - & - & 9 & 10.8 & 76 & 10.9 & \\
\hline $\mathrm{y}$ & 4 & 1.7 & - & - & 11 & 5.1 & - & - & - & - & 15 & 2.1 & $<0.001^{\text {b235 }}$ \\
\hline açlldıktan...gün sonra & 23 & 9.6 & 4 & 2.8 & 11 & 5.1 & - & - & - & - & 38 & 5.4 & \\
\hline ...tarihine kadar & 8 & 3.3 & 6 & 4.1 & 14 & 6.5 & - & - & 7 & 8.4 & 35 & 5.0 & \\
\hline Üretim izin tarihi ve sayısı & 239 & 100.0 & 143 & 98.6 & 208 & 97.2 & 19 & 100.0 & 83 & 100.0 & 692 & 98.9 & $0.06^{b}$ \\
\hline Orijin ülke (TM veya ülke ) & 222 & 92.9 & 137 & 94.5 & 199 & 93.0 & 19 & 100.0 & 77 & 92.8 & 654 & 93.4 & $0.77^{a}$ \\
\hline Kullanım bilgisi & 130 & 54.4 & 46 & 31.7 & 117 & 54.7 & 19 & 100.0 & 54 & 65.1 & 366 & 52.3 & $<0.001^{\mathrm{a} 245}$ \\
\hline $\begin{array}{l}\text { Kullanım bilgisi yanında son } \\
\text { kullanım tarihi }\end{array}$ & 84 & 35.1 & 44 & 30.3 & 79 & 36.9 & 7 & 36.8 & 23 & 27.7 & 237 & 33.9 & $0.50^{\mathrm{a}}$ \\
\hline Muhafaza şartları & 224 & 93.7 & 127 & 87.6 & 191 & 89.3 & 11 & 57.9 & 54 & 65.1 & 607 & 86.7 & $<0.001^{\mathrm{a} 123}$ \\
\hline $\begin{array}{l}\text { Özel işlem görmüş veya belli fiziksel } \\
\text { şartlarda bulunan ürünlerde ürünün } \\
\text { adı ile birlikte uygulanan işlem veya } \\
\text { fiziksel şart }\end{array}$ & 58 & 24.3 & 16 & 11.0 & 32 & 15.0 & 4 & 21.1 & 3 & 3.6 & 113 & 16.1 & $<0.001^{\mathrm{a} 15}$ \\
\hline Tatlandırıcı uyarısı & 1 & 0.4 & 4 & 2.8 & 13 & 6.1 & - & - & 10 & 12.0 & 28 & 4.0 & $<0.001^{\mathrm{c} 35}$ \\
\hline
\end{tabular}

aPearson Kikare Testi ${ }^{b}$ Fisher Exact Test ${ }^{c}$ Likehood Ratio, ${ }^{1}$ Temel besinler ${ }^{2}$ Atıştırmalıklar ${ }^{3}$ Tek başına tüketilmeyen besinler ${ }^{4}$ Bebek mamaları ${ }^{5}$ Diğer besinler

ögeleri miktarları üzerinden hesaplanarak "doğru”, "yanlış” ve “\% değer” olarak değerlendirilmiştir. TG’ın \%36.4'ünün, AG’ın \%23.4'ünün, TBTG’ın \%22.0’sinin, BM'nın \%42.1'inin, DG'ın ise \%16.9'unun enerji değerlerinin etikette verilen verilerden hesaplanan enerjiyi tam olarak sağladığı belirlenmiştir. Enerji değeri doğruluğu yönünde besin etiketi grupları arasındaki fark istatistiksel olarak anlamlı bulunmuş, tüm grupların istatistiksel olarak birbirinden farklı olduğu görülmüştür $(\mathrm{p}<0.001)$.

Besin etiketi grupları posa ve sodyum, vitamin ve mineral içerik bilgileri yönünden karşılaştırıldığında posa miktarının en çok BM'da (\%78.9), en az TG ve DG'da (\%8.4), sodyum miktarının en çok BM'da (\%89.5) en az TG'da (\%9.6), vitamin miktarının en çok BM'da (\%42.1), en az AG'da (\%2.8), mineral miktarının ise en çok BM'da (\%26.3), en az DG'da (\%7.2) belirtildiği saptanmıştır. Bu bilgilere göre besin etiketi grupları arasında posa, sodyum, vitamin ve mineral içerik bilgileri yönünden anlamlı farklılık saptanmıştır (sirasiyla $\mathrm{p}<0.001, \mathrm{p}<0.001, \mathrm{p}<0.001, \mathrm{p}<0.001$ ). Posa ve sodyum bilgisi için AG ve BM, vitamin ve mineraller 
Tablo 3. Besin etiketlerinin besin içeriği özellikleri

\begin{tabular}{|c|c|c|c|c|c|c|c|c|c|c|c|c|c|}
\hline \multirow{3}{*}{$\begin{array}{l}\text { Besin etiketlerinde olması gereken } \\
\text { beslenme bilgileri }\end{array}$} & \multicolumn{12}{|c|}{ Besin grupları } & \multirow{3}{*}{$\mathbf{p}$} \\
\hline & \multicolumn{2}{|c|}{$\begin{array}{c}\text { TB }^{1} \\
(n=239)\end{array}$} & \multicolumn{2}{|c|}{$\begin{array}{c}A^{2} \\
(n=145)\end{array}$} & \multicolumn{2}{|c|}{$\begin{array}{c}\text { TBTB }^{3} \\
(n=214)\end{array}$} & \multicolumn{2}{|c|}{$\begin{array}{c}\text { BM }^{4} \\
(n=19)\end{array}$} & \multicolumn{2}{|c|}{$\begin{array}{c}\mathrm{DB}^{5} \\
(\mathrm{n}=83)\end{array}$} & \multicolumn{2}{|c|}{$\begin{array}{l}\text { Toplam } \\
(n=700)\end{array}$} & \\
\hline & $\mathbf{n}$ & $\%$ & $\mathbf{n}$ & $\%$ & $\mathbf{n}$ & $\%$ & $\mathbf{n}$ & $\%$ & $\mathbf{n}$ & $\%$ & $\mathbf{n}$ & $\%$ & \\
\hline \multicolumn{14}{|l|}{ Etiket bilgilerinin enerji değeri $(n=231)$} \\
\hline \multicolumn{14}{|l|}{ Bu ölçütü karşılayan n sayısı } \\
\hline Doğru & 87 & 36.4 & 34 & 23.4 & 47 & 22.0 & 8 & 42.1 & 14 & 16.9 & 190 & 27.1 & \multirow{4}{*}{$<0.001^{\mathrm{b} 6}$} \\
\hline Yanlış & 108 & 45.2 & 87 & 60.0 & 68 & 31,7 & 11 & 57,9 & 44 & 53.0 & 318 & 45.4 & \\
\hline Etiket yok & 38 & 15.9 & 23 & 15.9 & 96 & 44.9 & - & - & 25 & 30.1 & 182 & 26.0 & \\
\hline \% değer & 6 & 2.5 & 1 & 0.7 & 3 & 1.4 & - & - & - & - & 10 & 1.4 & \\
\hline Enerji & 195 & 81.9 & 121 & 83.4 & 112 & 52.3 & 19 & 100.0 & 58 & 69.9 & 505 & 72.1 & $<0.001^{\mathrm{a} 35}$ \\
\hline Protein & 196 & 82.0 & 119 & 82.1 & 106 & 49.5 & 19 & 100.0 & 55 & 66.3 & 495 & 70.7 & $<0.001^{\mathrm{a} 6}$ \\
\hline Karbonhidrat & 192 & 80.3 & 121 & 83.4 & 111 & 51.9 & 19 & 100.0 & 57 & 68.7 & 500 & 71.4 & $<0.001^{\mathrm{a} 35}$ \\
\hline Nişasta & 5 & 2.1 & 10 & 6.9 & 4 & 1.9 & 19 & 100.0 & - & - & 19 & 2.7 & $0.03^{\mathrm{b} 35}$ \\
\hline Nişasta bitkisel temelli & 4 & 1.7 & 18 & 12.4 & 2 & 0.9 & - & - & - & - & 24 & 3.4 & $0.00^{\mathrm{b} 2}$ \\
\hline Şeker alkolleri & 1 & 0.4 & - & - & 3 & 1.4 & - & - & - & - & 4 & 0.6 & $0.51^{\mathrm{b}}$ \\
\hline Şeker & 16 & 6.7 & 58 & 40.0 & 28 & 13.1 & 2 & 10.5 & 4 & 4.8 & 108 & 15.4 & $<0.001^{\mathrm{a} 23}$ \\
\hline Tatlandırıcı & 1 & 0.4 & 5 & 3.4 & 6 & 2.8 & - & - & 5 & 6.0 & 17 & 2.4 & $0.03^{\mathrm{b} 12}$ \\
\hline Yağ & 182 & 76.2 & 116 & 80.0 & 108 & 50.5 & 19 & 100.0 & 50 & 60.2 & 475 & 67.9 & $<0.001^{\mathrm{a} 245}$ \\
\hline Doymuş yağ asitleri & 37 & 15.5 & 66 & 45.5 & 45 & 21.0 & 7 & 36.8 & 8 & 9.6 & 163 & 23.3 & $<0.001^{\mathrm{a} 125}$ \\
\hline Tekli doymamış yağ asitleri & 11 & 4.6 & 16 & 11.0 & 22 & 10.3 & 6 & 31.6 & 8 & 9.6 & 63 & 9.0 & $<0.001^{\mathrm{a} 14}$ \\
\hline Çoklu doymamış yağ asitleri & 8 & 3.3 & 18 & 12.4 & 20 & 9.3 & 6 & 31.6 & 8 & 9.6 & 60 & 8.6 & $<0.001^{\mathrm{a} 14}$ \\
\hline Trans yağ asitleri & 6 & 2.5 & 16 & 11.0 & 3 & 1.4 & 19 & - & 2 & 2.4 & 27 & 3.9 & $<0.001^{\mathrm{c} 2}$ \\
\hline Kolesterol & 17 & 7.1 & 8 & 5.5 & 18 & 8.4 & 1 & 5.3 & 6 & 7.2 & 50 & 7.1 & $0.88^{\mathrm{a} 25}$ \\
\hline Posa & 20 & 8.4 & 65 & 44.8 & 26 & 12.1 & 15 & 78.9 & 7 & 8.4 & 133 & 19.0 & $<0.001^{\mathrm{a} 24}$ \\
\hline Sodyum & 23 & 9.6 & 64 & 44.1 & 33 & 15.4 & 17 & 89.5 & 5 & 6.0 & 142 & 20.3 & $<0.001^{\mathrm{a} 24}$ \\
\hline \multicolumn{14}{|l|}{ Vitaminler } \\
\hline Grafik & - & - & - & - & - & - & - & - & - & - & - & - & \multirow{2}{*}{$<0.001^{\mathrm{a} 4}$} \\
\hline Sayı değer & 23 & 9.6 & 4 & 2.8 & 17 & 7.9 & 8 & 42.1 & 4 & 4.8 & 56 & 8.0 & \\
\hline \multicolumn{14}{|l|}{ Mineraller } \\
\hline Grafik & - & - & - & - & - & - & - & - & 1 & 1.2 & 1 & 0.1 & \multirow{2}{*}{$<0.001^{\text {b4 }}$} \\
\hline Sayı değer & 49 & 20.5 & 11 & 7.6 & 13 & 6.1 & 5 & 26.3 & 6 & 7.2 & 84 & 12.0 & \\
\hline
\end{tabular}

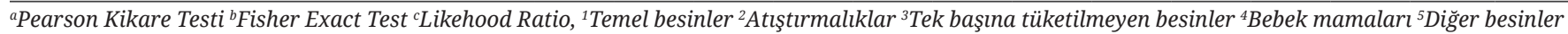

için ise yalnızca BM’ın diğer gruplardan farklı olduğu belirlenmiştir.

\section{TARTIŞMA}

Tüketicilerin sağlıklı beslenme ve sağlıklı besin seçimi yönündeki tutum ve davranışları her geçen gün artmakta, dolayısıyla besin etiketleri yaşam biçimi içerisinde sağlıklı beslenme davranışının kazanılmasında önemli rol oynamaktadır (14-16). Besin endüstrisinin gelişimi ile artan paketli besinlerin tüketiciye sunumu sonucunda besin etiketlerinin de doğru ve ayrıntılı bilgi sağlaması tüketiciler yönünden büyük bir gereksinim olarak kabul edilmektedir (14). Tüketicilerin besin etiketlerine göre sağlıklı besin şeçimleri daha az yağ, kolesterol, şeker ve yüksek miktarda posa, vitamin ve mineral alımını sağlamaktadır $(3,17)$. Besin etiketlerinin okunabilirliği ve anlaşılabilirliği konusunda yapılan çalışmalarda tüketiciler, etiket üzerindeki özellikle beslenme ve sağlık bilgilerinin kafa karıştırıcı, anlaşılmaz ve okunamaz olduğunu ifade etmişlerdir (14,17-20). Besin 
etiketlerinin güvenirliğini inceleyen çalışmalarda, tüketicilerin besin etiketlerine güvenmediklerini, bilgilerin yanıltıcı olduğunu düşündüklerini bu nedenle sağlıklı besin seçiminde endişe duyduklarını göstermiş, besin etiketlerinin tüketicileri yanıltmadan, besinin doğasını ve özelliklerini yansıtan ayrıntılı ve kesin bilgiler sağlaması gerektiğinin önemi vurgulanmıştır $(15,17)$.

Bu çalışmada, beslenme açısından riskli grup olarak kabul edilen bebeklerin beslenmesinde, temel veya ek besin olarak kullanılan kaşık mamalarının hepsinde bilgilendirici etiket bulunması sevindiricidir. Yine toplum bireylerinin beslenmesinde çok önemli yere sahip olan ekmek, süt, yoğurt gibi temel besinlerin çoğunlukla etiket içerdiği görülmektedir. Temel besin sınıfındaki ürünlerin benzerleri piyasada bulunabildiğinden, tüketicinin her ürün konusunda bilgilendirilmesi ve ürünler arasında karşılaştırma yapabilmesine olanak sağlanması gerekmektedir. Diğer yandan, günlük enerji alımında önemli bir role sahip atıştırmalıkların çoğunlukla etiket içermedikleri görülmüştür. Fazla enerji alımı yoluyla obezite nedeni olarak gösterilen bu besinlerin, özellikle beslenme bilgilerinin tüketiciye tam ve doğru olarak sunulması gerekmektedir. Bu çalışmada da incelenen besinlerden bebek mamaları (\%100) ile atıştırmalıkların (\%71.7) diğer besin gruplarına göre beslenme bilgi beyanlarının daha yüksek olduğu saptanmıştır.

Diğer yandan, tüketicilerde besin etiketlerinde verilen bilgilerin doğruluğu yanında besin etiketinde bazı besin ögelerinin olduğundan daha az veya fazla gösterildiği endişeleri de bulunmaktadır. Şüpheye götüren diğer bir konu da etiketler üzerinde yer alan ve görece kavram olan "düşük" veya "yüksek" beyanlarıdır (17). Bu nedenle besin üreticilerinin tüketime sundukları besinlerde etiket bilgilerini tam ve doğru olarak bildirmeleri ve etiketleme güvenirliğini sağlamaları da zorunlu hale gelmektedir (21). Bu çalışmada incelenen besinlerin etiketinde beyan edilen yine aynı etiket üzerinde bildirilen makro besin ögeleri miktarlarına göre hesaplanarak karşılaştırılmıştır. Temelbesinlerin ancak\%36.4'ünün, atıştırmalıkların \%23.4'ünün, tek başına tüketilmeyen besinlerin \%22.0'sinin, bebek mamalarının \%42.1'inin, diğer besinlerin ise \%16.9'unun etikette beyan edilen enerji değerini karşıladığı saptanmıştır.

Günümüzde sağlanması kolay, ucuz, ancak besin değeri düşük, enerji içeriği yüksek olan besinlerin obezitenin gelişmesinde büyük etkisi bilinmektedir $(3,16,19)$. Eğlence, ikram veya yeni tatlar için tüketilse de atıştırmalık besinler, günlük beslenme içerisinde enerji alımına ihmal edilemeyecek katkı sağlamaktadırlar. Bu nedenle atıştırmalık besinler de besin etiketleri ve beslenme bilgileri açısından dikkate alınması gereken bir besin grubudur $(16,17,20)$.

Obezite karmaşık yapısından dolayı çevre, yaşam tarzı, gibi pek çok sayısız etmen ile ilişkilendirilmiştir ancak, obezite ve bilişsel unsurlar ilişkisi son dönemlerde araştırmaların ilgi odağı olmaya başlamıştır $(14,22)$. Ares ve arkadaşlarının (23) çalışmasında akılcı tüketicilerin, sezgisel tüketicilere göre satın almayı düşündükleri besinlerin etiket bilgilerini karşlaştırarak karar verdikleri bildirilmiştir. Bu çalışmada, en çok yanlış hesaplanan besin grubunun atıştırmalıklar (\%60.0) olduğu saptanmıştır. İncelenen besin etiketlerinin bir kısmında (\%1.4) \% değer verildiğinden enerji hesaplaması yapılamamıştır. $\mathrm{Bu}$ durumda, tüketicilerin besin etiketlerinden edindikleri bu bilgilerin kullanılabilirliği düşündürücüdür.

Çalışmalarda tüketicilerin en çok besinin enerji ve yağ içeriği bilgilerine baktıklarını, herhangi bir hastalık durumunda ise besin etiketinde hastalıkla ilişkili besin ögelerini inceledikleri bildirilmiştir (14,19,22,24). Tüketiciler tarafından sıklıkla kullanılan besinlere ait sağlık bilgileri ancak uygun şekilde görülebilir ve okunabilir şekilde tasarlanmış besin etiketleri ile sağlanabilir (24). Yasa gereği etiketteki zorunlu bilgilerin başka yazılar ya da resimlerle örtülü veya kesik olmamalıdır. Oysa bu çalışmada incelenen bebek mamaları dışında hiçbir besin grubunun bu zorunluluğu karşılayamadığı görülmüştür.

Paketlenmiş besinin besin ögeleri içeriği konusundaki bilgiler, tüketicilerin besinin sağlıklı olma durumunu değerlendirebilmelerine ve bilinçli seçimler yapabilmelerine olanak sağlamaktadır. Besin seçimlerinin iyileştirilmesi amacıyla besinlerin 
etiketleme çalışmaları birçok ülke politikalarınca desteklenmektedir $(4,25)$. Yine bu çalışmada besin etiketleri üzerindeki yazıların fonla kontrastlığı ve yazıların silinmez karakterde, okunabilir renk ve okunabilir boyutta olma özelliği hiçbir besin grubunda tam olarak karşılanamadığı belirlenmiştir. Buna ek olarak az da olsa bazı besin etiket ve ambalajlarında hastalık önleme, iyileştirme ve tedavi etme özelliği olduğunu bildiren, ima eden ifadeler olduğu, bebek mamalarında ise sağlık beyanı bulunmadığı saptanmıştır.

Birçok ülkede besin güvenliğinin sağlanabilmesine, besin üretiminin denetlenebilmesine yönelik yasal düzenlemeler yapılmakta olup ülkemizde de "Türk Gıda Kodeksi Gıda Etiketleme ve Tüketicileri Bilgilendirme Yönetmeliği” ile besin etiketlerinde bulunması gereken zorunlu bilgiler yayınlanmıştır $(6,14)$.

$\mathrm{Bu}$ çalışma kapsaminda incelenen besinlerin üretimine ait ticari bilgiler incelendiğinde besin grupları etiketlerinde üretici, imalatçı, paketleyici, ithalatçı, ihracatçı veya dağıtıcı firmalara ait her türlü, bilginin tüm besin gruplarında yüksek düzeyde yer aldığı görülmüştür.

$\mathrm{Bu}$ çalışmanın sonucunda, tüketicilerin kullanımına sunulan besinlerin etiket beslenmebilgilerininyetersiz ancak ticari bilgilerin yüksek düzeyde karşılandığı belirlenmiştir. Tüketiciye sunulan ve erişimi kolay olan bu besinlerin etiketleri hem bireylerin beslenme durumlarının değerlendirilip sağlıklı besin seçimleri yapabilmelerinde, hem de beslenmeyle ilintili hastalıkların önlenmesinde etkilidir. Ayrıca geniş kapsamlı beslenme araştırmalarında doğru verilerin toplanabilmesinde yalnızca tüketiciler için değil aynı zamanda başta diyetisyenler olmak üzere tüm sağlık araştırmacıları için önemli bilgi kaynaklarıdır. Bu nedenle yasal düzenlemelerle halk sağlığını koruma amaçlanırken üretim ve etiketleme uygulamaları da ilgili organlarca denetlenmelidir.

Çıkar çatışması - Conflict of interest: Yazarlar çıkar çatışması olmadığını beyan ederler. - The authors declare that they have no conflict of interest.

\section{KAYNAKLAR}

1. Güneş FE, Aktaç Ş, İrem B, Korkmaz O. Tüketicilerin gıda etiketlerine yönelik tutum ve davranışları. Akademik Gida 2014;12(3):30-37.

2. Aygen FG. Tüketicilerin besin etiketi incelenmesi konusundaki tutum ve davranışları. İşletme Araştırmaları Dergisi 2012;4(3):28-54.

3. Graham DJ, Heidrick C, Hodgin K. Nutrition label viewing during a food-selection task: Front-of-package labels vs nutrition facts labels. J Acad Nutr Diet 2015;115:16361646.

4. Cannoosamy K, Pugo-Gunsam P, Jeewon R. Consumer knowledge and attitudes toward nutritional labels. J Nutr Educ Behav 2014;46(5):334-340.

5. World Health Organization 2006. Global Strategy on Diet, Physical Activity and Health: A framework to monitor and evaluate implementation. WHO Library Cataloguing-in-Publication Data. Available at: http:// www.who.int/ dietphysicalactivity/Indicators\%20 English.pdf. Erişim Tarihi: 01.07.2017.

6. Türk Gıda Kodeksi Gıda Etiketleme ve Tüketicileri Bilgilendirme Yönetmeliği Yayımlandığı R.G. Tarihi: 26.01.2017, No:29960 mükerrer. http://www. resmigazete.gov.tr/eskiler/2017/01/20170126M1-6.htm

7. Topuzoğlu A, Hıdıroğlu S, Ay P, Önsüz F, İkiışık H. Tüketicilerin gıda ürünleri ile ilgili bilgi düzeyleri ve sağlık risklerine karşı tutumları. TSK Koruyucu Hekimlik Bülteni 2007;6(4):253-258.

8. Gida Teknolojisi. Gida Üretiminde Hijyen 2. http://hbogm. meb.gov.tr/modulerprogramlar/kursprogramlari/ gida/ moduller/GidaUretimindeHijyen2.pdf . Erişim Tarihi:22.07.2017.

9. Besler HT, Buyuktuncer Z, Uyar MF. Consumer understanding and use of food and nutrition labeling in Turkey. J Nutr Educ Behav 2012;44(6):584-591.

10. Türkiye Beslenme Rehberi 2015 (TÜBER). T.C. Sağllk Bakanlığı Yayın No:1031 Basım: Kayhan Ajans ISBN: 978-975-590-608-9.

11. Arıcan F. Tüketicinin Korunmasında Gıda Etiketleri. Ulusal Mevzuat ve Avrupa Birliği Mevzuatı. Hacettepe Beslenme ve Diyetetik Günleri III. Mezuniyet sonrası eğitim kursu konuşma metinleri Türkiye Diyetisyenler Derneği, Ankara,2011.s.48-54.

12. Ekşi A. Gıda etiketlerindeki sağlık ve besin öğesi beyanları ve tüketicinin bilinçlendirilmesine katkısı. Hacettepe beslenme ve diyetetik günleri III. Mezuniyet sonrası eğitim kursu konuşma metinleri Türkiye Diyetisyenler Derneği, Ankara, 2011. s.62-64. 
13. Thompson T. The gluten-free labeling rule: What registered dietitian nutritionists need to know to help clients with gluten-related disorders. J Acad Nutr Diet 2015;115(1):13-16.

14. Sharf M, Sela R, Zentner G, Shoob H, Shai I, Stein-Zamir C. Figuring out food labels. Young adults' understanding of nutritional information presented on food labels is inadequate Appetite 2012;58:531-534.

15. Bandara BES, De Silva DAM, Maduwanthi $\mathrm{BCH}$, Warunasinghe WAA I. Impact of food labeling information on consumer purchasing decision: with special reference to Faculty of Agricultural Sciences. Proc Food Sci 2016;6:309-313.

16. Gonzalez-Vallejo C, Lavins BD, Carter KA. Analysis of nutrition judgments using the Nutrition Facts Panel. Appetite 2016;105:71-84.

17. Talati Z, Pettigrew S, Hughes C, Dixon H, Kelly B, Ball $\mathrm{K}$, et.al. The combined effect of front-of-pack nutrition labels and health claims on consumers' evaluation of food products. Food Qual Prefer 2016;53:57-65.

18. Miller LM, Cassady DL. Making healthy food choices using nutrition facts panels. The roles of knowledge, motivation, dietary modifications goals, and age. Appetite 2012;59:129-139.
19. Elfassy T, Yi S, Eisenhower D, Lederer A, Curtis CJ. Use of sodium information on the nutrition facts label in New York city adults with hypertension. J Acad Nutr Diet 2015;115:278-283.

20. Muller L, Prevost M. What cognitive sciences have to say about the impacts of nutritional labelling formats. J Econ Psychol 2016;55:17-29.

21. Tonkin E, Coveney J, Meyer SB, Wilson AM, Webb T. Managing uncertainty about food risks e consumer use of food labelling. Appetite 2016;107:242-252.

22. Masic U, Christiansen P, Boyland EJ. The influence of calorie and physical activity labelling on snack and beverage choices. Appetite 2017;112:52-58.

23. Ares H, Mawad F, Giménez A, Maiche A. Influence of rational and intuitive thinking styles on food choice: Preliminary evidence from an eye-tracking study with yogurt labels. Food Qual Prefer 2014;31:28-37.

24. Becker MW, Sundar RP, Bello N, Alzahabi R, Weatherspoon L, Bix L. Assessing attentional prioritization of front-of-pack nutrition labels using change detection. Appl Ergon 2016;54:90-99.

25. Cavaliere A, De Marchi E, Banterle A. Investigation on the role of consumer health orientation in the use of food labels. Public Health 2017;147:117-149. 